\title{
Efficiency of apple juice clarification with using of nano- sized mineral oxides
}

\author{
Anastasiia Sachko, Igor Kobasa, \\ Olesya Moysyura, Mariia Vorobets
}

Yuriy Fedkovych Chernivtsi National University, Chernivtsi, Ukraine

\section{Keywords: \\ Clarification \\ Apple juice \\ Titanium dioxide \\ Silicon dioxide \\ Bentonite}

\section{Article history:}

Received

20.06.2019

Received in revised

form 21.11.2019

Accepted

30.06.2020

\section{Corresponding} author:

Anastasiia Sachko

E-mail:

an.sachko@

chnu.edu.ua

DOI:

$10.24263 / 2304-$

974X-2020-9-2-8

\section{Abstract}

Introduction. The aim of presented work was the investigation of the efficiency of clarification of direct pressing apple juice with utilization of nano-sized powders of both silicon dioxide and titanium dioxide, modified silicon dioxide powder in comparison with bentonite clay.

Materials and methods. The juice used for laboratory testing was squeezed from "Glory to the Winners" apples. Modified silicon dioxide powder (AMD-2, specific surface area $280 \mathrm{~m}^{2} / \mathrm{g}$ ) and nanodispersed powders of both silicon dioxide (specific surface area $300 \mathrm{~m}^{2} / \mathrm{g}$ ) and titanium dioxide (specific surface area $50 \mathrm{~m}^{2} / \mathrm{g}$ ) were selected as clarifiers. For comparison, we used bentonite clay (specific surface area $160 \mathrm{~m}^{2} / \mathrm{g}$ ). The optical density was measured with spectrophotometr, the content of dry substances was evaluated refractometrically, $\mathrm{pH}$ and titratable acidity was determined according to known methods.

Results and discussion. Prospects of mineral oxides of titanium and silicon utilization for clarification of apple juice have been shown. It was established that the most effective clarifiers were $\mathrm{SiO}_{2}$ powder and suspension. Optimal weight of $\mathrm{SiO}_{2}$ is $2.5 \mathrm{~g}$ per 1 liter of juice; steep time is not more than 24 hours. The form (in powder or suspension) has no significant effect on the result of clarification.

The worst clarification ability bentonite clay demonstrated. It was confirmed that utilization bentonite in suspension form increases the clarification efficiency. Growth a mass of bentonite from 0.1 to $2.5 \mathrm{~g}$ per 1 of juice impairs its optical properties.

The effect of temperature of clarification processes on its efficiency and influence of the "juice-clarifier" contact time on the physical-chemical properties of the finished product were investigated. It was shown that the result of clarification is better at low temperature $\left(4^{\circ} \mathrm{C}\right)$, and all the used oxides are able to slow down the flow of natural processes of fermentation of raw apple materials. It was found that more than 24 hours contact of juice with clarifiers has a negative influence on the clarification result for all tested samples.

Conclusion. Nano-dispersed oxides of titanium (IV) and silicon (IV) could be effectively utilized to clarify of fresh direct pressing apple juice. Their clarifying ability is higher than bentonite clay and they could be brought in juice without pre-treatment, in the form of powder. 


\section{- Food Technology -}

\section{Introduction}

According to [1] main substances which cause the turbidity in apple juice could be divided into two groups. The first are substances which settle over time, among them: mold, bacteria, plant cell fragments, protein-tannin complexes. The second - substances which formed colloidal or true solutions: polymeric carbohydrates, proteins, polyphenols (tannins), organic acids, alcohol and other. Because of such composition, clarification of apple juice is the necessary stage of producing.

There are two different processes during juice preparation: clarification and fining [1]. It is well known that the production of apple juice includes both the removal of suspended material and prevention of the development of juice turbidity after bottling. Precipitation of suspended substances before filtration often called clarification. Measures, which are taking to remove soluble materials that have the potential to form after-bottling sediment are called fining [1].

For some fruit juices, a natural clarification process is possible under the prolonged storage. This process is the result of chemical reactions that occur in the juice under the action of natural enzymes [2]. The duration of such self-clarification process is from two weeks to 2-3 months [3]. This method can be successfully applied to grape juice, but not for freshly squeezed apple juice [4].

Modern process of apple juice clarification consists of several stages: adding of clarifiers agent, clarification process, vacuum filtration and final filtration. Most useful clarifiers in technological process are enzymes. Many publications are devoted to the study both of the influence of natural and synthetic enzymes on the process of juices clarification and the mechanism of this process $[2,5-7,8]$. The principle of enzymatic clarification is based on the destruction of the negatively charged surface layer of protein-carbohydrates complexes and protein-pectin complexes under the action of enzymes [8]. Due to the action of electrostatic attraction forces, floccules are formed and the system is destroyed [1].

A classical well-researched fruit juice clarifier is a bentonite clay [1,9]. The clarification effect of bentonite and other minerals is explained by the combination of three processes: adsorption, coagulation and sedimentation. Bentonite clays (like oxides we study) have a developed surface that is why the adsorption of small proteins and other molecules occur on the clay surface. At the same time, the processes of aggregation of proteins, starches and tannins with bentonite particles in the system take place $[1,1,7]$. They are caused by the redistribution of electrical charges in the system and the change in charge of coats of proteincarbohydrates complexes. The result of these processes is coagulation. In general case, coagulation is not accompanied by the chemical interaction of the clarifier and the juice components [1].

It should be borne in mind that the properties of bentonite and other adsorbents and their clarification ability depend on place of origin and method of its pre-treatment [10,11]. Such pre-treatment can include $\mathrm{pH}$ control, selection of concentration range, temperature conditions, the way of making the suspension in the juice and others. That is why results described in different sources could be slightly different.

An important role is played by the method of bringing of bentonite in the juice: in the form of powder or in suspension. It is believed that the use of the suspension is much more effective [12]. Adsorption capability of bentonites increases with their swelling capability in water [13]. To verify this statement, we introduced all clarifiers into the juice as a suspension and powder.

Our previous work was devoted to the study of the effectiveness of lighting white and red wines using mineral clarifiers [14]. We have shown that mineral nanosized titanium and 
silicon oxides are much more effective fining agents for red and white grape wines than bentonite and saponite. However, the process of clarifying apple juice is different from the process of clarifying wine materials and not necessarily clarifiers, which were effective for grape wines, will be effective for apple juice.

Unlike enzymes, the utilization of mineral oxides for clarify juices is practically not described in the literature. In addition to a wide range of works about clarification properties of bentonite clays $[12,15]$, some attention is paid to zeolites [16] and sepiolites $[17,18]$, and utilization of shungite for water treatment [19]. Membrane methods of clarification of fruit and vegetable juices using $\mathrm{TiO}_{2}$ and $\mathrm{Al}_{2} \mathrm{O}_{3}$ are described [20,21]. However, this is not enough to assess the prospects of using oxides as clarificators. That is why these studies are a logical continuation of the previous ones [4] in order to evaluate the possibility of using mineral titanium oxides and silicon to clarify apple juice.

The aim was to investigate the prospect of using mineral clarifiers, as they have a number of significant advantages: they are relatively cheap, environmentally safe, easily removed from the finished product, they can be reused after proper cleaning.

\section{Materials and methods}

\section{Materials}

$\mathrm{SiO}_{2}$ powder with highly developed surface area (AMD-2) and nanodispersed powders of both $\mathrm{SiO}_{2}$ and $\mathrm{TiO}_{2}\left(\mathrm{~S}_{\mathrm{BET}}=50 \mathrm{~m}^{2} / \mathrm{g}\right)$ were selected as clarifiers. Nanodispersed $\mathrm{SiO}_{2}-$ product which was obtained by flaming hydrolysis of $\mathrm{SiCl}_{4}$ vapors in an air-aqueous mixture at a temperature of 700 to $1100{ }^{\circ} \mathrm{C}$. The size of the particles is $10-20 \mathrm{~nm}$, the specific surface area $\mathrm{S}_{\mathrm{BET}}=300 \mathrm{~m}^{2} / \mathrm{g}$. AMD-2 - high-disperse silicon dioxide modified by depolymerizate D-4, specific surface area $S_{\mathrm{BET}}=280 \mathrm{~m}^{2} / \mathrm{g}$. For comparison, we used the classic bentonite clarifier, the formula of which is $\mathrm{Al}_{2}\left[\mathrm{AlSi}_{3} \mathrm{O}_{9} \times(\mathrm{OH})\right](\mathrm{OH})_{2} \times \mathrm{nH}_{2} \mathrm{O}\left(\mathrm{S}_{\mathrm{BET}}=160 \mathrm{~m}^{2} / \mathrm{g}\right)$.

The juice used for laboratory testing was squeezed from "Glory to the Winners" apples of one crop, steeped for 12 hours at $\sim 4^{\circ} \mathrm{C}$ and decanted from the precipitate. The final juice output was $60 \%$.

\section{Sample preparation}

All samples were divided into two groups. In the first - the clarifier was added to the juice directly in the form of powder. In the second case, the clarifier was added to the juice in the form of a suspension. For suspensions obtaining, a portion of the powder was stirred in hot $\left(\sim 80^{\circ} \mathrm{C}\right)$ water and left for 12 hours at room temperature. Then it was mixed thoroughly and injected into the juice. The preparation of AMD suspension is not possible because of its high hydrophobicity.

\section{Methods}

The optical density was measured with Agilent Cary 60 spectrophotometr at wavelength $\lambda=400 \mathrm{~nm}$, absorbing layer thickness 3,070 [22]. The comparison solution was water. The content of dry substances was evaluated refractometrically (Atago PAL-1 BLT Digital Brix Refractometer), $\mathrm{pH}$ value with device $\mathrm{pH}-150 \mathrm{MI}$ [23].

The titrated acidity (in terms of malic acid) was determined by titration of the sample with $0.1 \mathrm{~N}$ alkali solution [24]. 


\section{Results and discussion}

\section{Influence of the clarifier mass and form on juice turbidity}

The bentonite utilization for the clarification of juices at the industrial level is minimized now, but the applications of cytosan [25] in combination with ultrafiltration and nanofibrous membranes are widely described in the literature nanofibrous membranes[25,26].

There are several ways to use bentonite clays for juices clarifying. The first is the shortterm thermostatation of the juices with a clay suspension at $60^{\circ} \mathrm{C}$ under the constant stirring conditions. Stirring and increasing of temperature intensify the lighting process [12,27].

The second way is the long staying of the mixture of juice with clarifier. It is believed that the most effective bentonite operates at concentrations of 400-500 g per 1 ton of juice at exposure time 12-24 hours. That is why we chose $0.1-0.5-2.5 \mathrm{~g} / \mathrm{l}$ (or $0.01-0.05-0.25$ $\mathrm{g} / 100 \mathrm{ml}$ of apple juice) for powders that have brought into the juice without pre-treatment and $0.5 \mathrm{~g} / \mathrm{l}(0.05 \mathrm{mg} / 100 \mathrm{ml}$ juice $)$ when oxides were added as suspension form.

For indication of temperature influence on clarification result all investigation were carried out under the temperatures $4{ }^{\circ} \mathrm{C}$ and $20^{\circ} \mathrm{C}$. On the one hand, under the temperature increasing we can suspect the intensification of aggregation and coagulation processes. On the other hand, the juice may deteriorate for a day and become unusable for further processing.

In the first stage of research, the clarifiers were placed in apple juice, kept for 24 hours at a constant temperature, decanted from the precipitate. The optical density of the juices was then measured. The juices were then centrifuged for 5 minutes $\left(1500 \mathrm{~min}^{-1}\right)$ and the optical density was again measured.

Figure 1 illustrates the dependence of the optical density of the juice on the weight of the clarifier $\left(4^{\circ} \mathrm{C}\right.$, before centrifugation). The diagram shows that the best result shows nanodispersed $\mathrm{SiO}_{2}$ in the form of powder, and the effect is better, the greater the weight of the powder. The efficiency of the illuminators decreases in the row:

\section{Powders $\quad \mathrm{SiO}_{2}>\mathrm{TiO}_{2}>\mathrm{AMD}>$ bentonite}

When we bringing clarifiers in juice in the form of a suspension, we see a similar pattern, but the efficiency of bentonite significantly increases:

$$
\text { Suspension } \quad \mathrm{SiO}_{2}>\mathrm{TiO}_{2}>\mathrm{AMD}>\text { bentonite }
$$

In view of the above at $4{ }^{\circ} \mathrm{C}$, the efficiency of clarifiers decreases in the series: $\mathrm{SiO}_{2}$ powder \& susp > $\mathrm{TiO}_{2}$ powder \& susp > bentonite susp>AMD > bentonite powder 


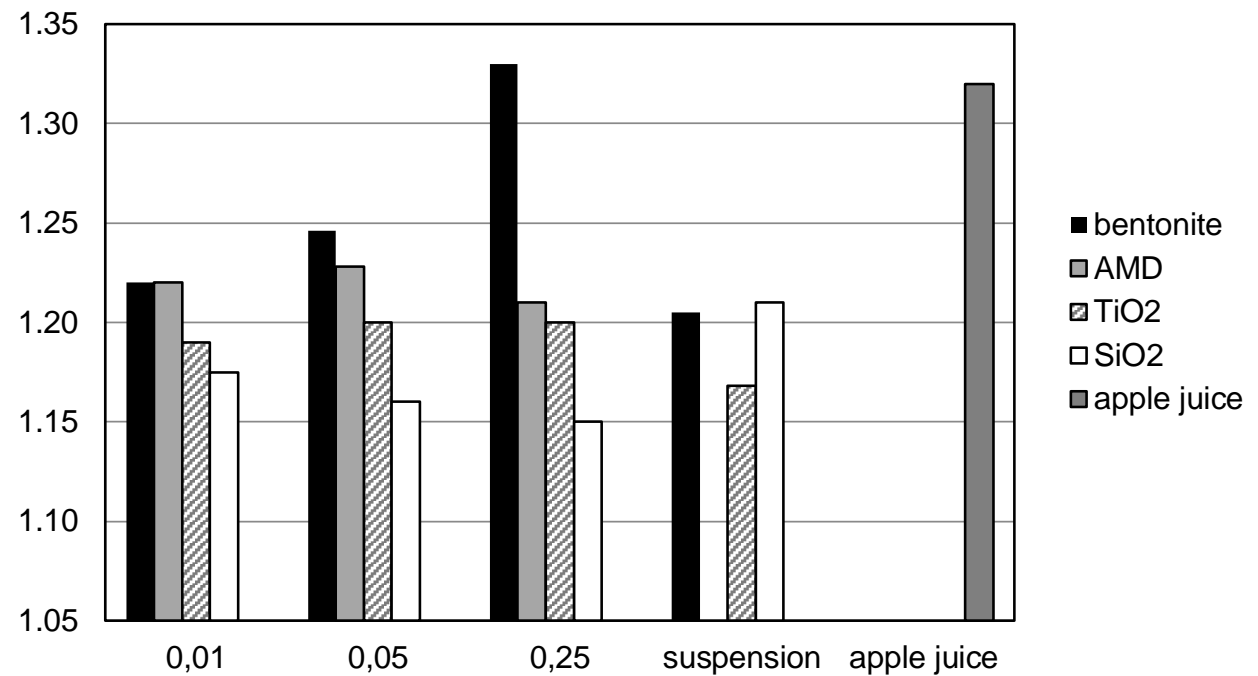

Figure 1. Dependence of the optical density of the juice on the weight of the clarifier $(\mathrm{g} / 100 \mathrm{ml}$ juice) compared to the apple juice without clarifier $\left(4{ }^{\circ} \mathrm{C}\right.$, before centrifugation)

Figure 2 shows the dependence of the optical density of the clarified juices on the weight of the clarifier after centrifugation. It is obvious that centrifugation, as an additional stage of technological clarification of juices, results in a decreasing in their optical density compared to non-centrifuged samples. However, it should be noted that the decrease in optical density for the clarifiyed samples was negligible and did not affect the overall result.



Figure 2. Dependence of the optical density of the juice on the weight of the clarifier $(\mathrm{g} / 100 \mathrm{ml}$ juice) compared to the apple juice without clarifier $\left(4^{\circ} \mathrm{C}\right.$, after centrifugation) 
The same experiments were carried out with juices samples under the $20{ }^{\circ} \mathrm{C}$ (imitation of production workshop conditions). It is interesting to note that clarification process was not so effective as under higher temperature. The optical density values of all samples were higher than those obtained for lower temperatures (Figure 3).

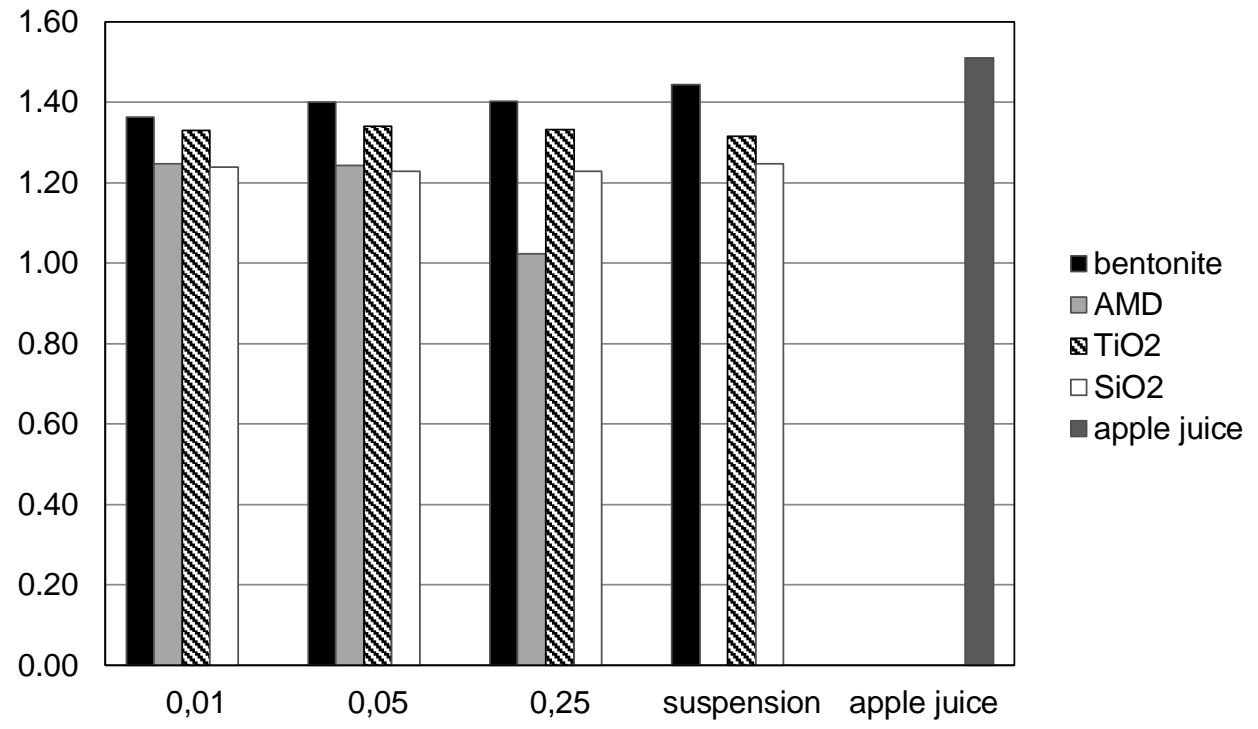

Figure 3. Dependence of the optical density of the juice on the weight of the clarifier $(\mathrm{g} / 100 \mathrm{ml}$ juice) compared to the apple juice without clarifier $\left(20^{\circ} \mathrm{C}\right.$, before centrifugation)

Figure 3 shows that, at $20^{\circ} \mathrm{C}$, there is no significant dependence of the optical density of juices on the clarifier mass, unlike the previous case. For bentonite only, the clarifying efficiency decreases slightly with the increasing of the powder mass.

Talking about the significant difference of values for using clarifiers in the form of powder or suspension is also meaningless. The result of their action is close. After centrifugation, the optical density of juices with and without clarifier additives slightly decreased (Figure 4).

Summarizing the results described above, we can conclude that at $20^{\circ} \mathrm{C}$ the most effective clarifier was hydrophobic AMD ( $0.25 \mathrm{~g}$ sample), the rest of the substances can be placed in a row accordingly to reducing their clarifying efficiency:

\section{$\mathrm{SiO}_{2}$ powder \& susp > $\mathrm{TiO}_{2}$ powder \& susp > bentonite powder \& susp}

Authors [28] show that for bentonites from different fields, efficiency is directly related to the surface area: the larger is the surface area than clarification process is more effective. On the one hand, difference in clarification ability of the samples may occur due to different adsorption capacity of the substances at different temperatures, on the other hand, titanium and silicon oxides can slow the fermentation processes in the juice. 


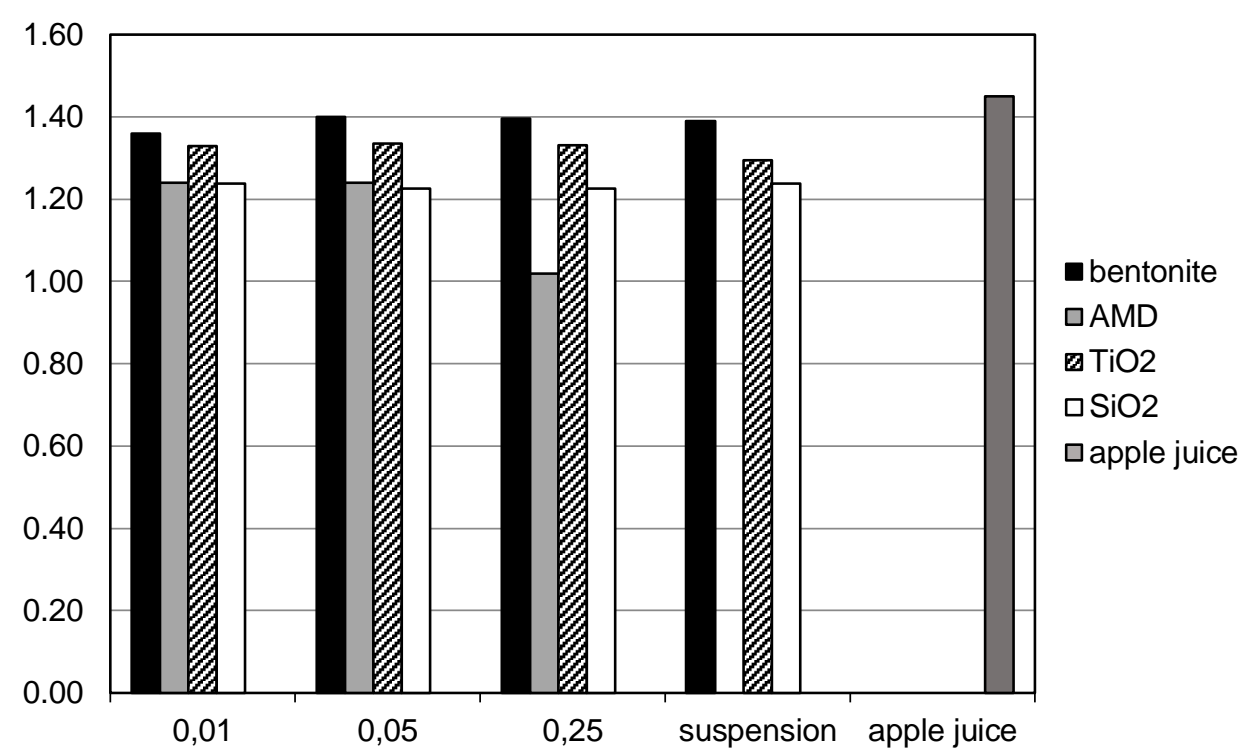

Figure 4. Dependence of the optical density of the juice on the weight of the clarifier (g/100 ml juice) compared to the apple juice without clarifier $\left(20{ }^{\circ} \mathrm{C}\right.$, after centrifugation).

\section{Evaluation of physico-chemical changes in juice-clarifier system with time}

For evaluation of physico-chemical properties of (juice+clarifier) system through the time the measurements of optical density, general acidity (in terms of malic acid), $\mathrm{pH}$ value and dry substances content were carried out. For these series of experiments the clarifier was added in juice in powder form powder mass was $0.01 \mathrm{~g} / 100 \mathrm{ml}$ of juice).

\section{Optical density}

The question "how long does it take to keep the juice mixer together for optimal result" still remains open. It depends on type of juice, $\mathrm{pH}$-value, temperature and clarifier nature. To determine the effect of time of steep, a series of apple juices with mineral clarifiers were prepared. The optical density was measured on the first, second and third days. For this purpose, the samples were decanted from the clarifier and centrifuged immediately before measurements.

Figure 5 shows the optical density clarified juices dependence on contact time juiceclarifier. From the above results it is concluded that clarification process was more successful for $4{ }^{\circ} \mathrm{C}$ than for $20^{\circ} \mathrm{C}$. In addition, temperatures of $15-25{ }^{\circ} \mathrm{C}$ are considered optimal for fermentation of apple raw materials [15]. Therefore, the experiment was carried out at $4{ }^{\circ} \mathrm{C}$ to slow the fermentation process. 




Figure 5. Dependence of optical density of clarified juices on time of standing with clarifier powder. For comparison, the curve 1 is apple juice without clarifiers addition that have undergone the sa me processing stages

From the presented results we can conclude that it is not necessary to storage the juices with the clarifiers for a long time. Although, the results are described by the authors [12] indicate that bentonite should be effective for apple juice clarification at high temperatures $\left(75^{\circ} \mathrm{C}\right.$ ) and preserving mixture up to three days. Such effect they explained by the intensification of coagulation processes in juice-clarifier system. At the same time authors authors [29] authors announce that there are three main factors for reaching of optimal condition for fruit juice clarification with bentonite and gelatin: temperature $\left(30-70{ }^{\circ} \mathrm{C}\right), \mathrm{pH}$ (4-6) and short time of contact (40-120 min).

\section{Acidity, pH value and dry substances content}

The process of clarification essentially depends on $\mathrm{pH}$ value of juice. So, for potato juice it was shown that maximum adsorption of the acid-soluble fraction occurs at $\mathrm{pH} 5.0$. The working conditions recommended for obtaining a protein-free potato juice is acidification to $\mathrm{pH}$ 4.5. [30]. For clarification of fruit juices with bentonite-gelatin mixture $\mathrm{pH}=4-6$ was recommended [29].

In our case the $\mathrm{pH}$ value correction was not necessary for our samples. Values of $\mathrm{pH}$ and general acidity of juices after clarification were almost indistinguishable from the values obtained for pure juice and amounted to $4.00 \pm 0.04$ and $0.40 \pm 0.05 \%$, respectively. The content of dry substances after clarification was slightly less than for pure juice (Table 1).

Physical-chemical properties of juices after clarification did not change essentially after five days steeping. Values were fixed at 1, 2, 3 and 5 days. Only apple juice without any additions shows a slight increasing of all parameters which could be caused with the flow of 
fermentation processes. Similar effects were observed by the authors [14,31] for using bentonite for grape wines clarification.

Table 1

Average values of physicochemical parameters of apple juice with and without clarifiers $\left(4^{\circ} \mathrm{C}\right)$

\begin{tabular}{|l|c|c|c|}
\hline \multicolumn{1}{|c|}{ Clarifier } & Brix, \% & Generat acidity, \% & pH \\
\hline & \multicolumn{3}{|c|}{ Days 1, 2, 3 and 5 } \\
\hline Bentonite & $12.4 \pm 0.1$ & $0.40 \pm 0.05$ & $3.99 \pm 0.04$ \\
\hline $\mathrm{AMD}$ & $12.3 \pm 0.1$ & $0.40 \pm 0.05$ & $4.00 \pm 0.04$ \\
\hline $\mathrm{TiO}_{2}$ & $12.2 \pm 0.1$ & $0.40 \pm 0.05$ & $3.98 \pm 0.04$ \\
\hline $\mathrm{SiO}_{2}$ & $12.3 \pm 0.1$ & $0.40 \pm 0.05$ & $3.99 \pm 0.04$ \\
\hline $\begin{array}{l}\text { Juice without } \\
\text { additions }\end{array}$ & \multicolumn{3}{|c|}{} \\
\hline Days 1-3 & $(12.9-13.2) \pm 0.1$ & $(0.40-0.44) \pm 0.05$ & $3.97-4.00 \pm 0.04$ \\
\hline Day 5 & $13.4 \pm 0.1$ & $0.46 \pm 0.05$ & $4.02 \pm 0.04$ \\
\hline
\end{tabular}

General acidity and $\mathrm{pH}$ value of oxides-free apple juice increasing slightly with steeping time. It is known that during the fermentation of fruit raw materials the concentration of acids in juice could increase. At the same time partially transformation of malic acid into lactic acid takes place. In addition, the fermentation process may be accompanied by the formation of succinic and other organic acids [32]. According to [33], the general acidity of the juices may slightly decrease in the process of fermentation, or increase slightly. Such changes are determined by the variety of apples and storage conditions. Similar regularities were described for properties of clarified apple juice in 4 weeks storage under $4{ }^{\circ} \mathrm{C}$ [34].

The constancy of physical-chemical properties of juices while they steep with clarifiers indicates on partially or fully cessation of the fermentation processes. This effect may be related both to the observance of the low temperature regime and to the pronounced antibacterial and antifungal action of titanium oxides and silicon [35,36]. For these substances bacteria growth inhibition was observed under the dark condition. Our samples were stored in the refrigerator also under the dark condition.

\section{Conclusions}

1. Mineral nano-sized oxides of titanium (IV) and silicon (IV) should be successfully used for apple juice clarification. Of all the substances tested, the classic absorbent - bentonite clay shown the worst performance as a clarifier.

2. It was shown that clarification process was more efficient at low temperature $\left(4^{\circ} \mathrm{C}\right)$ then at room temperature $20^{\circ} \mathrm{C}$. By reducing the efficiency of clarification at low temperatures, the test substances can be arranged in the following order:

$$
\mathrm{SiO}_{2}>\mathrm{TiO}_{2}>\mathrm{AMD}>\text { bentonite }\left(4^{\circ} \mathrm{C}\right)
$$

At $20^{\circ} \mathrm{C}$ the best clarification effect had $A M D$ in concentration $2.5 \mathrm{~g} / \mathrm{l}$ of juice. The other substances lose their clarification ability in row:

$$
\mathrm{SiO}_{2}>\mathrm{TiO}_{2}>\text { bentonite }\left(20^{\circ} \mathrm{C}\right)
$$

3. It was confirmed that bentonite possessed much better clarification ability as a suspension form then in powder. On contrary, there is no significant difference for nano-sized $\mathrm{SiO}_{2}$ and $\mathrm{TiO}_{2}$. These oxides are equally effective both in suspension and in powder form. 
According to our results, the optical density of juices after clarification grows with the time of steeping of mixture. That is why optimal clarification time at $4{ }^{\circ} \mathrm{C}$ was 12 hours.

4. Addition of investigated oxides in apple juice leads to the retardation of fermentation processes in juice. It is interesting to note that clarification ability did not correlate with the antimicrobial activity which generally increased from $\mathrm{TiO}_{2}$ to $\mathrm{SiO}_{2}$ [36]. For these substances bacteria growth inhibition was observed under the dark condition. Our samples were stored in the refrigerator also under the dark condition.

\section{References}

1. Kilara A., Van Buren J. P. (1989), Clarification of Apple Juice. Processed Apple Products, Springer, New York, pp. 83-96.

2. Yamasaki M., Kato A., Chu S.-Y., Akima K. (1967), Pectic Enzymes in the Clarification of Apple Juice, Agricultural and Biological Chemistry, 31(5), pp. 552-560.

3. Genovese D.B., Elustondo M.P., Lozano J.E. (1997), Color and Cloud Stabilization in Cloudy Apple Juice by Steam Heating During Crushing, Journal of Food Science, 62, pp. 1171-1175.

4. McLellan M.R., Race E.J. (1995), Grape juice processing. In: Ashurst P.R. (eds) Production and Packaging of Non-Carbonated Fruit Juices and Fruit Beverages, Springer, Boston.

5. Ceci L., Lozano J. (1998), Determination of enzymatic activities of commercial pectinases for the clarification of apple juice, Food Chemistry, 61(1-2), pp. 237-241.

6. Sheu M., Wiley R., Schlimme D. (1987), Solute and Enzyme Recoveries in Apple Juice Clarification using Ultrafiltration, Journal of Food Science, 52, pp. 732-736.

7. Oliynyk S., Mel'nyk L., Samchenko I., Tkachuk N., Loginova O., Kisterska L. (2019), Influence of shungite treatment methods on its absorption properties and on water treatment quality for beverages production, Ukrainian Food Journal, 8(4), pp. 891-902.

8. Chatterjee S., Chatterjee S., Chatterjee B.P., Arun K. Guha (2004), Clarification of fruit juice with chitosan, Process Biochemistry, 39(12), pp 2229-2232.

9. Matko S.V., Mank V.V., Melnyk L.M., Zhestereva N.A (2004), Lighting apple juice with natural adsorbent - paligorskite, Food and processing industry, pp. 24-25.

10. Djordjević M., Šereš Z., Došenović T., Šronja-Simović D., Maravić N., Kukić D., Nikolić I., Djordjević M. (2018), Sugar beet molasses purification by bentonite addition: Analysis of quality enhancement and treatment conditions, LWT, 93, pp. 142-149.

11. Melnyk L., Melnyk Z., Kryvorotko V. (2013), Methods of recovering schungite's adsorptive properties after processing red beet juice, Ukrainian Journal of Food Science, 1(2), pp. 223-227.

12. Koyuncu H., Kul A.R., Çalımlı A., Yıldız N., Ceylan H. (2007), Adsorption of dark compounds with bentonites in apple juice, LWT - Food Science and Technology, 40(3), pp. 489-497.

13. Olsen A. (1987), Low Technology Water Purification by Bentonite Clay and Moringa Oleifera Seed Flocculation as Performed in Sudanese Village: Effect on Schistosoma Mansori Cericariae, Water Resources, 21(5), 81-92.

14. Sachko A., Kobasa I., Moysyura O. (2017), Perspectives of utilization of nanodispesive materials based on $\mathrm{TiO}_{2}, \mathrm{SiO}_{2}$ and $\mathrm{SiO}_{2}-\mathrm{TiO}_{2}$ for wine fining, Journal Food and Environment Safety of the Suceava University. Food Engineering, XVI (4), pp. 216-221. 
15. Jalali M., Jahed E., Haddad Khodaparast M.H., Limbo S., Mousavi Khaneghah A. (2014), Evolution of bentonite and gelatin effects on clarification of variety of date fruit Kaluteh juice with response surface methodology, International Food Research Journal, 21(5), pp. 1893-1899.

16. Woloshchuk A.G., Kobasa I.M., Bogdanyuk M.P., Petrova G.P. (2013), Natural mineral sorbents in food technology, Scientific Bulletin of Chernivtsi University, Chemistry, 658, pp. 141-149.

17. Mirzaaghaei M., Goli S.A.H., Fathi M. (2016), Application of sepiolite in clarification of pomegranate juice: changes on quality characteristics during process, Int. J. Food Sci. Technol., 51, pp. 1666-1673.

18. Mirzaaghaei M., Sayed Amir, Hossein Goli, Milad Fathi (2017), Clarification of apple juice using activated sepiolite as a new fining clay, Clay Minerals, 52 (4), pp. 497-508.

19. Melnyk L., Turchun O., Tkachuk N., Kutz A., Melnyk Z. (2014), Water-alcohol adsorbing cleaning out of higher alcohols by shungite, Ukrainian Journal of Food Science, 2(2), pp. 312-317.

20. Nasabi M., Labbafi M., Khanmohammadi M. (2017), Optimizing nano $\mathrm{TiO}_{2}$ assisted decoloration process for industrial date syrup utilizing response surface methodology, $J$ Food Process Eng., 40(5), pp.1-9.

21. Severcan S.S., Uzal N., Kahraman K. (2020), Clarification of pomegranate juice using PSF microfiltration membranes fabricated with nano $\mathrm{TiO}_{2}$ and $\mathrm{Al}_{2} \mathrm{O}_{3}, J$ Food Process Preserv, pp. 1-14.

22. Joslyn Maynard (2014), Methods in Food Analysis: Applied to Plant Products, Saint Louis. Elsevier Science.

23. Sadler G.D., Murphy P.A. (2010), pH and Titratable Acidity. Food Analysis. Springer, Boston.

24. Ashurst P.R. (2008), The chemistry and technology of soft drinks and fruit juices, John Wiley \& Sons.

25. Veleirinho B., Lopes-da-Silva J.A. (2009), Application of electrospun poly(ethylene terephthalate) nanofiber mat to apple juice clarification, Process Biochemistry, 44(3), pp. 353-356.

26. Jahed E., Khodaparast M. H. H., Mousavi Khaneghah A. (2014), Bentonite, temperature and $\mathrm{pH}$ effects on purification indexes of raw sugar beet juice to production of inverted liquid sugar, Applied Clay Science, 102, pp. 155-163.

27. Erdogăn B., Demirci Ş., \& Akay Y. (1996), Treatment of sugar beet juice with bentonite, sepiolite, diatomite and quartamin to remove color and turbidity, Applied Clay Science, 11(1), pp. 55-67.

28. Bilbao A., Irastorza A., Duenas M., Fernandez K. (1997), The effect of temperature on the growth of strains of Kloeckera apiculata and Saccharomyces cerevisiae in apple juice fermentation, Letters in Applied Microbiology, 24(1), pp. 37-39.

29. Lindner P., Ben-Gera I., Keren R. (1981), Precipitation of proteins from potato juice with bentonite, Journal of the Science of Food and Agriculture, 32(12), pp. 1177-1182.

30. Vinogradov V.A., Zagoruyko V.A., Kulev S.V. (2013), Research of the technological process of complex stabilization of wine materials against colloidal and crystalline opacities, Viticulture and winemaking, 43, pp. 83-88.

31. Herrero M., Cuesta I., García L. A., Díaz M. (1999), Changes in Organic Acids During Malolactic Fermentation at Different Temperatures in Yeast-Fermented Apple Juice, Journal of the Institute of Brewing, 105(3), pp. 191-196. 
32. Tokar A. Yu. (2015), Changing the content of organic acids during fermentation of fruit worts, Bulletin of the Uman NUS, 2, pp.39-43.

33. Kobasa I., Vorobets M., Arsenieva L. (2016), Nanosides titanium dioxide as an antibacterial admicxture for the food packaging materials, Journal Food and Environment Safety of the Suceava University, Food Engineering, XV(4), pp. 306-311.

34. Cai M., Xie C., Lv Y., Yang K., Sun P. (2020), Changes in physicochemical profiles and quality of apple juice treated by ultrafiltration and during its storage, Food Sci Nutr., 8, pp. 2913-2919.

35. Adams L. K., Lyon D. Y., Alvarez P. J. J. (2006), Comparative eco-toxicity of nanoscale $\mathrm{TiO}_{2}, \mathrm{SiO}_{2}$, and $\mathrm{ZnO}$ water suspensions, Water Research, 40(19), pp. 3527-3532.

36. Mu H., Chen Y., Xiao N. (2011), Effects of metal oxide nanoparticles $\left(\mathrm{TiO}_{2}, \mathrm{Al}_{2} \mathrm{O}_{3}, \mathrm{SiO}_{2}\right.$ and $\mathrm{ZnO}$ ) on waste activated sludge anaerobic digestion, Bioresource Technology, 102(22), pp. 10305-10311. 